\title{
In memoriam: Wissam S. Al-Hashimi
}

\author{
Former IUGS Vice-President murdered in Iraq
}

Dr. Wissam S. Al-Hashimi has died. His daughter, Tara, reports that he was kidnapped early in the morning of August 24 while on his way to work. The ransom demanded by his abductors was paid by his family, but to no avail. He died of two bullet wounds to his head. Because his identification was taken from him, it took his family two weeks to find his body in a Baghdad hospital. Tragic indeed, and senseless.

Wissam was born in Baghdad, Iraq. He received his B.Sc. degree in geology-physics from Baghdad University in 1965. After completing the national military service, in 1967 he joined Mosul University in northern Iraq, where he worked as a demonstrator in the newly-established geological department. He left Iraq in 1968 to do post-graduate research and pursue his Ph.D. in England at the University of Newcastle-upon-Tyne. There he worked on the sedimentology and dolomitization of the limestone member of the Carboniferous Middle Limestone Group of Northumberland, northeast England.

After receiving his Ph.D. in 1972, AlHashimi returned to Baghdad to continue his professional career. Over the years he held a variety of responsible scientific and managerial positions in the Iraqi government, the Iraqi National Oil Company, and the Iraq Ministry of Oil. In the course of these endeavors, he was active on national, regional and international levels. Following the establishment of the Arab Geologist Association (AGA) in 1975, he was appointed the head of the Association's advisory committee. He served there until 1993, when he was elected Secretary General, and was re-elected to a second term in 1998. His positions in the Association enabled him to be involved in the organization of many international conferences, symposia and seminars. Dr. Al-Hashimi also served as Editor-in-Chief of the Association's bilingual geoscience magazine, Geoscience \& Arab Development. He was elected both Secretary General (1973) and President (2001) of the Geological Society of Iraq. On the international level, Dr. Al-Hashimi was elected to the Council of the International Association of Sedimentologists, where he served for two consecutive terms (1982-1990). In 1986, he participated in a workshop organized by Bob Ginsburg (University of Miami) that was dedicated to formulating an initiative that became the IUGS Global Sedimentary Geology Program. He was elected a Vice President of the IUGS in 1996, where he served until 2002. Al-Hashimi was the convener of the session on Petroleum Geology \& Reservoir Analysis at the 31st IGC (Rio de Janeiro,

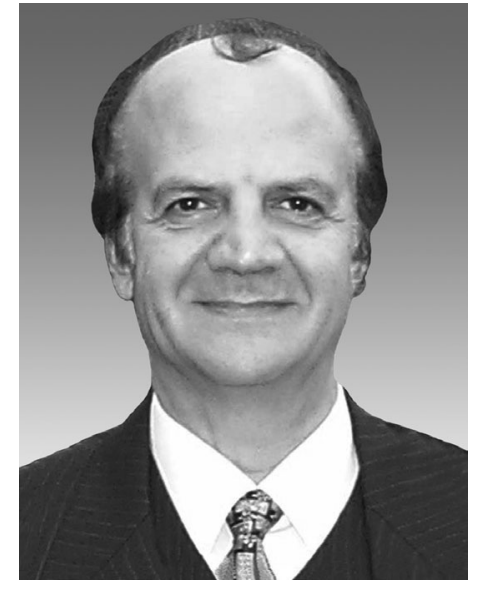

2000), and was a member of the Advisory Board of the 32nd IGC (Florence, 2004).

Dr. Al-Hashimi authored a large number of scientific papers, in both Arabic and English, published in local, Arab, and international journals, and covering a wide range of topics. These included carbonate sedimentology and diagenesis, petrology, mineralogy, geoarchaeology, engineering geology, underground storage, industrial rocks and minerals, and hydrology. He was also a regular contributor of analytical articles to newspapers in Iraq covering various political, oil, and water issues in the Middle East and the Arab world.

I came to know Wissam beginning in 1997, after he was elected a Vice-President of the IUGS. I saw him regularly over the six years that he served in that position. He impressed all of his IUGS colleagues with the quality of his preparation for the annual meetings of the Executive Committee, and with the honest, forthright, and thoughtful counsel that he offered at those meetings. Equally admirable, however, was the enormous personal effort required for him to attend those meetings, each of which always began and ended with a frequently dangerous 12-hour trip by bus or taxi from his home in Baghdad to and from Amman, Jordan, his closest connection to an international airline.

Over the years of our association, I came to appreciate and admire his integrity and deep commitment to science, especially to international scientific activities. Despite the professional isolation and other obvious difficulties of pursuing his scientific career while living in Iraq, his focus, drive, and enthusiasm were remarkable; he was undaunted by the challenges he faced. He was a fine scientist who could have forged a notable career in any country of his choosing. But Iraq was his homeland, and he was determined to serve there.
Since 2002, when his IUGS term ended, we carried on an active e-mail correspondence. Some was personal or was related to professional matters such as helping him to acquire needed reference materials, or helping him to contact other scientists in whose work he was interested, or publicizing scientific meetings that he was instrumental in organizing in Iraq or elsewhere in the middle East. Not surprising, however, is that some of our correspondence was political in nature, especially leading up to and during the current war in Iraq. Wissam was an avid student of U.S. politics, which interest I helped to advance by regularly sending him cogent articles collected from electronic and print media from the U.S. and around the world. He usually responded, sometimes at great length, with detailed comments and analysis based on his perspective and first-hand experiences in Iraq. His observations were especially interesting, because they frequently differed radically from published accounts. Wissam despaired at the wanton death and needless destruction inflicted on his country in the current conflict. He took satisfaction, however, from the fact that most of his scientific colleagues, including Americans, supported him and his country in their distress.

Along with other close colleagues, I last saw Wissam in August 2004 in Florence, Italy, at the 32nd IGC. There he presented two papers and co-chaired a session on dolomitization and dedolomitization. He was also the Iraqi representative to the Mediterranean Consortium of the Congress. We were pleased to see him looking well, and, as ever, actively engaged with scientific pursuits. We enjoyed visiting with him, sharing meals, and exchanging personal reflections on matters of science, politics, our families, and life.

In one of his messages to me Wissam commented that the neighborhood where he lived was very dangerous, and he feared for his life and the safety of his family. As a precaution, he took a different route to work every day. Tragically, that strategy ultimately failed him. Ironically, only two days before receiving word of his death, I expressed to mutual friends my concern about his welfare because my messages to him had gone unanswered for almost three weeks. Now we know why. The geological community has lost a dedicated scientist and a fine and very decent man. Worse, I lost a good friend.

\section{John M. Aaron}

IUGS Web Manager 2504 Charlestown Lane

Reston, VA, USA 20191

jaaron@his.com 